\title{
THE TYPE OF FOREST EDGE GOVERNS THE SPATIAL DISTRIBUTION OF DIFFERENT-SIZED GROUND BEETLES
}

\author{
Tibor Magura ${ }^{1}$ and GÁbor L. Lövei ${ }^{2}$ \\ ${ }^{1}$ Department of Ecology, University of Debrecen, H-4032 Debrecen, Egyetem tér 1, Hungary; \\ E-mail:maguratibor@gmail.com; https://orcid.org/0000-0002-9130-6122 \\ ${ }^{2}$ Department of Agroecology, Aarhus University, Flakkebjerg Research Centre \\ DK-4200 Slagelse, Denmark; E-mail: gabor.lovei@agro.au.dk \\ https://orcid.org/0000-0002-6467-9812
}

Worldwide human-induced habitat fragmentation intensifies the emergence of forest edges. In addition to these edges, there are edges evolved by natural processes. Edge-maintaining processes (natural vs. anthropogenic) fundamentally determine edge responses, and thus edge functions. Species with various traits show fundamentally different edge response, therefore the trait-based approach is essential in edge studies. We evaluated the edge effect on the body size of ground beetles in forest edges with various maintaining processes. Our results, based on 30 published papers and 221 species, showed that natural forest edges were impenetrable for small species, preventing their dispersal into the forest interiors, while both the medium and the large species penetrated across these edges and dispersed into the forest interiors. Anthropogenic edges maintained by continued human disturbance (agriculture, forestry, urbanisation) were permeable for ground beetles of all size, allowing them to invade the forest interiors. Overwintering type (overwintering as adults or as larvae) was associated with body size, since almost two-thirds of the small species, while slightly more than a third of both the medium and the large species were adult overwintering. Based on this, size-dependent permeability of natural edges may be related to overwintering type, which basically determines species tolerance to human disturbance.

Keywords: spatial distribution, ground beetles, body size, carabids, edge effect, filter function, meta-analysis.

\section{INTRODUCTION}

Over the 20th century, the focus of ecological research gradually shifted from the study of undisturbed ecosystems to disturbed or human-managed ones. This trend reflects the continued increase in habitat conversion, in parallel with the globally increasing resource use by the human population. 'Natu$\mathrm{ral}^{\prime}$ habitats, however, are not only shrinking but are also undergoing fragmentation, which inevitably creates more and more edges. Habitat edge is a type of ecotone, a transitional zone between adjacent ecological systems, with characteristics defined by space, time and the strength of interactions between the adjacent ecological systems (TURNER \& GARDNER 2015). 
Habitat edge is defined at the meso-spatial scale and community level. At the border between two neighbouring habitats, environmental parameters are gradually or abruptly altered, creating conditions that are considerably different from either of the adjacent habitats (Murcia 1995, Ewers \& Didham 2006). These conditions have a direct impact on the spatio-temporal distribution and dynamics of many species as well as their interactions. The totality of these is termed the "edge effect" (Murcia 1995).

Accumulated research on a wide range of organisms and diverse edge types has led to attempts to identify overarching mechanisms causing edge effects. Ries et al. (2004) suggested four such mechanisms: ecological flows, access to spatially separated resources, resource mapping, and species interactions. RIES and SisK (2004) presented a predictive model forecasting abundance changes near edges for any species in any landscape, and this can predict several but not all edge responses. Edge orientation (RiEs et al. 2004), temporal effects (RIEs et al. 2004), habitat fragmentation (RIEs et al. 2004, НARDT et al. 2013), edge contrast (Ries et al. 2004, Perras et al. 2013), the difference between habitat patch and matrix (Ewers \& Didham 2006), species traits (Peyras et al. 2013, Carvajal-Cogollo \& Urbina-Cardona 2015) and habitat suitability (Peyras et al. 2013) were claimed to account for the unexplained variation.

Processes maintaining habitat edges also influence the edge effect (STRAYER et al. 2003). A meta-analysis, focusing on forest edges, and on an abundant insect group, ground beetles (Coleoptera: Carabidae) shows that forest edges maintained by natural processes have significantly higher species richness than forest interiors, unlike edges under continued anthropogenic influence (history-based edge effect hypothesis, Magura et al. 2017). Species richness, however, is not the most sensitive indicator of the edge effect, because species with different traits may respond differently to the same stimuli (KoIvula et al. 2004, Gobbi \& Fontaneto 2008, Brigić et al. 2014, Magura 2017). A traitbased analysis could unearth otherwise hidden but important ecological patterns (NAGY et al. 2018), and neglecting the biology of organisms may derail attempts to understand their ecological responses (Lövei \& Magura 2006).

Body size is an essential and widely used proxy for various life-history parameters (Peters 1983). Body size not only influences morphology, physiology and fitness of the organism (Kingsolver \& Huey 2008), but is also linked to multiple life-history traits, including life span, fecundity, and behaviour (Chown \& Gaston 2010), as well as to spatial distribution (Jetz et al. 2004, DAVEY et al. 2005) and biotic interactions, with consequences on community dynamics, and ecological networks (Woodward et al. 2005). Consequently, changes in body size distribution within assemblages have important consequences for ecosystem functioning (Petchey \& Belgrano 2010, Ohlberger 2013).

To further articulate the history-based edge effect hypothesis, we compared the abundance of ground beetles of different body size (as a life history 
trait) classes captured at differently maintained forest edges and their respective interiors. We predicted that forest edges maintained by natural processes have significantly more large but not medium-sized or small ground beetles than their interiors, while edges with continued anthropogenic influence did not show such a trend.

\section{MATERIAL AND METHODS}

\section{Study and data selection}

To collect relevant data, we followed the procedure described in MAgura et al. (2017). We used the resulting dataset with the same inclusion criteria: a paper had to report data on the abundance of the same carabid species in both forest interior and its respective edge. From papers that studied carabids along transects, only data from the two extremes: the interiormost location and the edge were used.

\section{Classification of forest edges}

Forest edges were classified as either maintained by natural processes, or by human interventions/disturbance. When neither of the neighbouring habitats have been managed (e.g. intensive grazing) or disturbed (by e.g. fire) for $>50$ years, we considered the edge a "natural" one. Edges created by human intervention (forestry, urbanisation or agricultural cultivation), and where the above non-disturbance criteria did not hold, were considered to be maintained by disturbance. The particular type of ongoing human intervention was a secondary classification criterion.

\section{Data analyses}

The body size of beetles was characterised by body length (CHOwn \& GASTON 2010) and we classified carabids as small (geometric mean $<10.5 \mathrm{~mm}$ ), medium $(10.5-15 \mathrm{~mm}$ ) or large (>15 mm). We calculated geometric means (as suggested by CHOwn \& GAston 2010) from minimum and maximum body length values obtained from Hомвurg et al. (2014). Subsequently, all analyses were based on this classification (EleK \& Lövei 2007, Bell et al. 2017, KęDZior et al. 2020).

For statistical analyses, we calculated the unbiased standardised mean difference (Hedges' $g$ ) as a common effect size (Borenstein et al. 2009) as described in Magura et al. (2017). Subgroup meta-analysis considering the edge-maintaining forces as moderators (type of edge maintaining process; type of anthropogenic influence) was applied using a random-effects model with publication-level random factor. Heterogeneity in the data was tested by calculating $Q$ and $I^{2}$ values (Borenstein et al. 2009). We partitioned total variance $\left(Q_{\text {total }}\right)$ into within- $\left(Q_{\text {within }}\right)$ and between group $\left(Q_{\text {between }}\right)$ variances and tested them separately (Borenstein et al. 2009). Calculations were done using the MAd (DelRe \& Hoyt 2014) and metafor packages (VIechtbauer 2010) in the $R$ programming environment ( $R$ Core Team 2017). For further details, refer to Magura et al. (2017). 


\section{RESULTS}

During the literature search, 204 published papers were found. Only 53 papers contained species abundance data from both the forest interior and the forest edge. Of these papers, however, only 30 studies reported standard deviations and sample sizes for the mean abundance values (Appendix, Table S1). Eleven papers studied forest edges maintained by natural processes, while 19 papers forest edges under continued human influences. One paper studied simultaneously two types of anthropogenic edges. Of the 20 edges with human influences, 8 were created and maintained by agriculture, 9 by forestry, and 3 by urbanisation. The 30 papers reported abundance data from 221 ground beetle species, of which 74 were small, 52 medium, and 95 large species. Overall, our meta-analyses were based on 466 separate edge-to-interior comparisons of abundance data of these 221 ground beetle species (Appendix, Table S2).

Analysing all edges together, the abundance of small species was significantly higher in the edges than in the interior (Fig. 1a; Appendix, Table S3). A similar pattern occurred in both the edges maintained by natural processes and the edges with continued anthropogenic influence. However, analysing separately the types of anthropogenic edges, no such pattern was observed. The abundance of small species was similar in forest edges maintained by agriculture or forestry and the respective forest interiors (Fig. 1a; Appendix, Table S3). Except for the models on natural edges and edges disturbed by agriculture, both the total and the unexplained heterogeneities were significant (Appendix, Table S3). Egger tests indicated significant funnel plot asymmetry (Appendix, Table S4). The trim and fill method estimated 24 missing abundance data on the right side (Appendix, Fig. S1a), but adding these did not change the significance of the overall effect in the model (Appendix, Table S5).

Considering all edges together, there was no significant difference in the abundance of medium species between forest edges and their interiors (Fig. 1b; Appendix, Table S3). The same lack of significant difference was observed for both natural and human-disturbed edges (Fig. 1b; Appendix, Table S3). Except for the model on edges disturbed by agriculture, both the total and the unexplained heterogeneities were significant (Appendix, Table S3) but without significant funnel plot asymmetry (Appendix, Table S4). The trim and fill method estimated 13 missing abundance data on the right side of the funnel plot (Appendix, Fig. S1b). Adding these data, however, did not change the non-significance of the overall effect (Appendix, Table S5).

The abundance of large species was, however, significantly higher in the edges than in the interior (Fig. 1c; Appendix, Table S3). This significant difference, however, disappeared when edges with different maintaining forces were analysed separately (Fig. 1c; Appendix, Table S3). Both the total and the 
unexplained heterogeneities were significant (Appendix, Table S3), with significant funnel plot asymmetry (Appendix, Table S4). The trim and fill method, however, predicted no missing abundance data (Appendix, Fig. S1c), so the significant overall effect in the model did not change (Appendix, Table S5).

a)

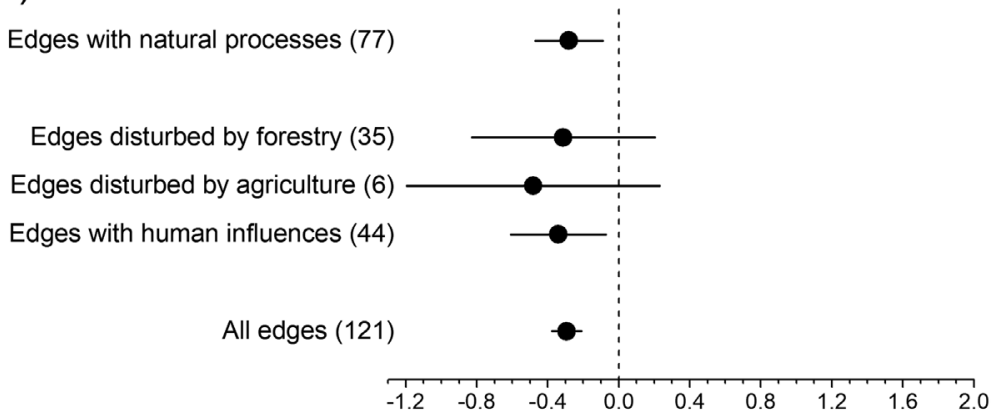

b)

Edges with natural processes (62)

Edges disturbed by forestry (24)

Edges disturbed by agriculture (10)

Edges with human influences (36)

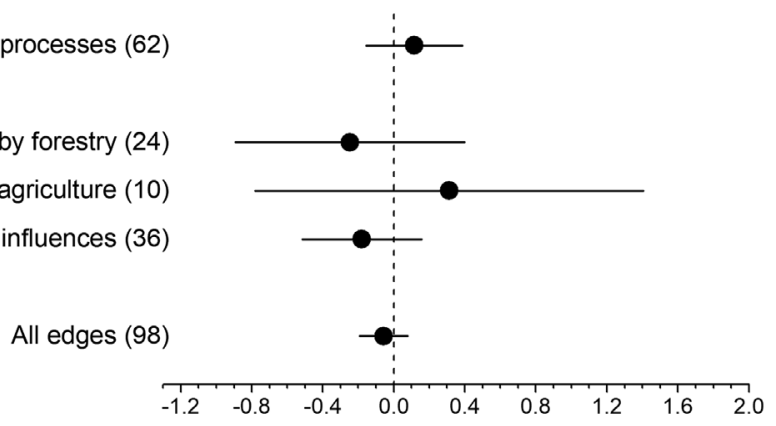

C)

Edges with natural processes (161)

Edges disturbed by urbanization (7)

Edges disturbed by forestry (45)

Edges disturbed by agriculture (30)

Edges with human influences (86)

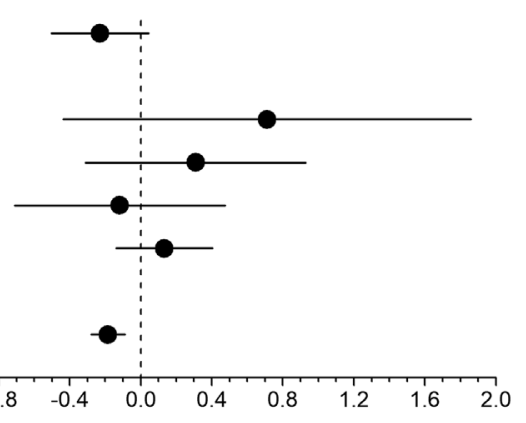

Mean effect size (Hedges' $g$ )

Fig. 1. Mean effect sizes of random-effect models ( $\pm 95 \%$ confidence interval) for the abundance of small (a), medium (b) and large ground beetle species (c). Values in brackets show the number of species abundances for which the mean effect size was calculated. A negative $g$ value indicates higher abundance in forest edges than interiors. The mean effect size is statistically significant when the confidence interval does not include zero 


\section{DISCUSSION}

Our results, studying the spatial distribution of 221 ground beetle species with different body size across variously maintained forest edges from 30 studies, shows that the abundance of small species was significantly higher in the forest edges maintained by natural processes compared to their interiors, but not in edges maintained by agriculture or forestry. Previous studies on the spatial distribution of ground beetles across edges examined the abundance of species displaying different feeding habits (MAGURA et al. 2019), habitat affinity (MAGura et al. 2017), and combined life history and ecological traits (dispersal power and habitat affinity, Magura \& Löver 2020b). The abundance of herbivorous, omnivorous, and predatory ground beetles were all significantly higher at edges with natural processes than their interiors, but no such difference was found in edges under continued human influence (MAGURA et al. 2019). Forest specialists were equally abundant at natural edges and their interiors, but they avoided edges disturbed by agriculture or urbanisation. The abundance of both the generalist and the open-habitat species were significantly higher at natural edges compared to the forest interiors, while these species reached similar abundance in the forestry-induced edges and the forest interiors (Magura et al. 2017). Open-habitat species with high dispersal power were significantly more abundant in natural edges than interiors, while became more similar in edges under anthropogenic interventions compared to their interiors. Contrary to this, the forest specialist species of limited dispersal power showed similar abundances in natural forest edges and interiors, but avoided edges influenced by agriculture or urbanisation (MAGURA \& Löver 2020b). In accordance with the history-based edge effect hypothesis (MaGura et al. 2017), our results clearly demonstrate, that the permeability (the filter function) of edges is essentially different depending on their history (maintaining processes) (Strayer et al. 2003, Magura et al. 2017).

The history of edges may determine the structural and functional properties as well as ecological conditions at edges (STrayer et al. 2003, Harper et al. 2015). Permeability is one of the most critical functional features of forest edges, as it fundamentally determines the community composition and organisation in adjacent habitats (LACASELla et al. 2015, BoETZL et al. 2016, KNAPP et al. 2019, MAGURA \& Löver 2019). Natural processes (succession after natural disturbances) maintain complex, stratified, heterogeneous, permanent, gradual forest ed ges extending up to several meters toward both the adjacent habitat and the forest interior (Magura 2002, Cadenasso et al. 2003, Harper et al. 2005, HARPER et al. 2014). Contrary to this, repeated human disturbance (agriculture, forestry, urbanisation) prevents the development of permanent, complex, and gradual edges, thus allowing only to evolve a simplified, abrupt, 
and often narrow edges (Strayer et al. 2003, Harper et al. 2005, Turner \& GARDNER 2015). This difference in the graduality (or abruptness) and permanence between natural and anthropogenic forest edges could be the main cause of the different permeability and filter function of edges (BowErsox \& Brown 2001, Strayer et al. 2003).

Our results show that anthropogenic forest edges allow small, medium, as well as large ground beetles to penetrate the forest interior. Natural forest edges also allow the dispersal of medium- and large species into the forest interior, but they prevent the influx of small species. Body size per se is a useful proxy, but cannot explain this size-dependent permeability of natural edges. Other life history and/or ecological traits associated with body size may underlie this pattern. For example, small carabids are usually macropterous or dimorphic, so they have high dispersal power (Kotze \& O'HARA 2003, JelasKa \& DuRbešıć 2009). Natural forest edges, being more dense, gradual and wider, can be impenetrable for species with high dispersal power. Indeed, most of the studied small species (54 out of 74 species; $73 \%$ ) were macropterous or dimorphic. Similarly, 65\% of the medium-sized species (34 out of 52 species) had also high dispersal power. However, only a small proportion of large species (24 out of 95 species; $25 \%$ ) were macropterous or dimorphic. Thus, it is unlikely that this size-dependent permeability of natural edges was related to dispersal power, because roughly the same proportion of small and medium species had high dispersal power, yet their spatial pattern was fundamentally different across natural edges. An ecological characteristic that may also be associated with small body size is habitat affinity. Open-habitat and generalist species tend to have smaller bodies (Kotze \& O'HARA 2003, Spake et al. 2016). Previously it was shown that natural forest edges were impermeable for both the open-habitat and generalist species (MaGura et al. 2017). In the present situation, the proportion of open-habitat and generalist species was $77 \%$ for the small, $64 \%$ for the medium-sized, and $43 \%$ for the large species. The ratio of open-habitat and generalist species in the small and the medium-sized species groups was mostly similar, but their spatial pattern along natural edges was significantly different. Therefore, in the present study, different habitat affinity could not explain the size-dependent permeability of natural edges. Interactions between the above life history (wing form) and ecological trait (habitat affinity) can be a meaningful indicator (MAGURA \& Löver 2020b) to test the size-dependent permeability of natural edges. The proportion of macropterous or dimorphic matrix (open-habitat and generalist) species was $64 \%$ for the small, $48 \%$ for the medium-sized, and $20 \%$ for the large species. Thus, the combination of these traits again does not support the different spatial pattern of variously sized species across natural edges. Another key trait to explain our result of the size-dependent spatial pattern of ground beetles along forest 
edges maintained by natural processes may be the species tolerance to human disturbance. Persistence in a habitat generally depends on the most vulnerable life stage. The larval stage of ground beetle ontogeny is the most vulnerable life stage, as larvae have limited mobility, weak chitinisation, and therefore narrower tolerance limits than adults (Lövei \& SunderLANd 1996). Generally, two reproduction types of ground beetles can be distinguished, species with summer larvae (also called spring breeders; species overwintering as adults) versus species with winter larvae (autumn breeders; species overwintering as larvae). Species overwintering as adults (species with summer larvae) are usually abundant in disturbed habitats, suggesting their tolerance to disturbance regimes (Ribera et al. 2001, Magura et al. 2002). In our dataset, there was a remarkable difference in the proportion of disturbance tolerant species with summer larvae among the body size categories, since $65 \%$ of the small species, $39 \%$ of the medium, and $36 \%$ of the large species were adult overwintering. This pattern correlates well with the differences in the spatial pattern of differently sized species along natural forest edges. Based on this, it seems that natural forest edges do not allow disturbance tolerant small species with summer larvae, to penetrate the forest interiors. This could be explained by the fact that the environmental conditions (e.g. temperature, humidity, solar radiation, habitat structure) at the edge cannot extend deep into the forest interior (STRAYER et al. 2003, Ries et al. 2004), thereby maintaining the strong environmental filter function of the stable, undisturbed forest interior (MAGURA \& Löver 2019). Strong environmental filter (e.g. high humidity, low temperature, thick leaf litter layer, closed canopy) in forest interior bordered by edges with natural processes prevent the survival and persistence of disturbance tolerant small species with summer larvae. Of course, in addition to the above mentioned, other traits (e.g. time of activity, hunting strategy, preference for environmental parameters) or their interactions may influence the spatial patterns of ground beetles across forest edges, as it was also indicated by the significant total and unexplained heterogeneity in the models. Moreover, other features of edges (type, size, age, and isolation of the neighbouring habitats, temporal effects and edge orientation), as well as the management type of the habitats adjacent to edges may also be important in determining the species pool and the spatial distribution of ground beetle species across edges (BLAKE et al. 1994, Holland 2002, Ries et al. 2004, De Smedt et al. 2019).

Our results show that ground beetle species in each size category were abundant in all edges. From the edges, beetles can easily disperse out of the forest, delivering insect pest and weed control in the adjacent habitats, especially in neighbouring agricultural fields (Roume et al. 2011, Leslie et al. 2014). However, other studies indicated limited spillover from forests into neighbouring arable fields (FerRante et al. 2017, Knapp et al. 2019). These inconsistent results suggest that insect pest and weed control potential may be related 
to habitat productivity, agricultural practices, farming methods, landscape heterogeneity, and species traits and identity (GAYER et al. 2019, JowetT et al. 2019, Knapp et al. 2019, Boetzl et al. 2020).

Based on our results, forest edges under continued anthropogenic influence were equally permeable for ground beetle species of all sizes, and they could easily invade the forest interiors. Their invasion may adversely affect the forest interior specialists (Кromp 1999, Magura et al. 2010, Magura et al. 2020), the composition and organisation of forest interior communities (PAILLet et al. 2010, TscharntKe et al. 2012, Magura et al. 2018, Fenoglio et al. 2020), and even ecosystem functions and services (TsCHARNTKE et al. 2012, Eötvös et al. 2018, Eötvös et al. 2020, Magura \& Lövei 2020a). Therefore, human-created and maintained edges should be restored (by softening these edges, SAmwaYs 2007) to develop a filter function similar to natural edges, ensuring continued ecosystem functions and services in forest fragments.

Acknowledgements - We are grateful to the National Research, Development and Innovation Fund for supporting this research (grant number OTKA K-131459).

\section{REFERENCES}

Bell, A. J., Phillips, I. D., Nielsen, S. E. \& Spence, J. R. (2017): Species traits modify the species-area relationship in ground-beetle (Coleoptera: Carabidae) assemblages on islands in a boreal lake. - PLOS ONE 12(12): e0190174. https://doi.org/10.1371/journal.pone.0190174

Blake, S., Foster, G. N., Eyre, M. D. \& Luff, M. L. (1994): Effects of habitat type and grassland management practises on the body size distribution of carabid beetles. - Pedobiologia 38: 502-512.

Boetzl, F. A., Schneider, G. \& Krauss, J. (2016): Asymmetric carabid beetle spillover between calcareous grasslands and coniferous forests. - Journal of Insect Conservation 20(1): 49-57. https://doi.org/10.1007/s10841-015-9838-6

Boetzl, F. A., Schuele, M., Krauss, J. \& Steffan-Dewenter, I. (2020): Pest control potential of adjacent agri-environment schemes varies with crop type and is shaped by landscape context and within-field position. - Journal of Applied Ecology 57(8): 1482-1493. https://doi.org/10.1111/1365-2664.13653

Borenstein, M., Hedges, L. V., Higgins, J. P. T. \& Rothstein, H. R. (2009): Introduction to Meta-Analysis. - John Wiley \& Sons Ltd., West Sussex, 452 pp.

Bowersox, M. A. \& Brown, D. G. (2001): Measuring the abruptness of patchy ecotones: A simulation-based comparison of landscape pattern statistics. - Plant Ecology 156(1): 89-103. https://doi.org/10.1023/A:1011953007555

Brigić, A., Starčević, M., Hrašovec, B. \& EleK, Z. (2014): Old forest edges may promote the distribution of forest species in carabid assemblages (Coleoptera: Carabidae) in Croa- 
tian forests. - European Journal of Entomology 111(5): 715-725. https://doi.org/10.14411/ eje.2014.090

Cadenasso, M. L., Pickett, S. T. A., Weathers, K. C., Bell, S. S., Benning, T. L., CarREIRo, M. M. \& DAwson, T. E. (2003): An interdisciplinary and synthetic approach to ecological boundaries. - BioScience 53(8): 717-722. https://doi.org/10.1641/00063568(2003)053[0717:AIASAT]2.0.CO;2

Carvajal-Cogollo, J. E. \& Urbina-Cardona, N. (2015): Ecological grouping and edge effects in tropical dry forest: reptile-microenvironment relationships. - Biodiversity and Conservation 24(5): 1109-1130. https://doi.org/10.1007/s10531-014-0845-9

Chown, S. L. \& Gaston, K. J. (2010): Body size variation in insects: a macroecological perspective. - Biological Reviews 85(1): 139-169. https://doi.org/10.1111/j.1469185X.2009.00097.x

Davey, A. J. H., Hawkins, S. J., Turner, G. F. \& Doncaster, C. P. (2005): Size-dependent microhabitat use and intraspecific competition in Cottus gobio. - Journal of Fish Biology 67(2): 428-443. https://doi.org/10.1111/j.0022-1112.2005.00736.x

Del Re, A. C. \& Hoyt, W. T. (2014): MAd: Meta-analysis with mean differences. https://doi.org/ https://cran.r-project.org/web/packages/MAd/MAd.pdf

Elek, Z. \& Lövei, G. L. (2007): Patterns in ground beetle (Coleoptera: Carabidae) assemblages along an urbanisation gradient in Denmark. - Acta Oecologica 32(1): 104-111. https://doi.org/10.1016/j.actao.2007.03.008

Eötvös, C. B., LöveI, G. L. \& Magura, T. (2020): Predation pressure on sentinel insect prey along a riverside urbanisation gradient in Hungary. - Insects 11(2): 97. https://doi. org/10.3390/insects11020097

Eötvös, C. B., Magura, T. \& Lövei, G. L. (2018): A meta-analysis indicates reduced predation pressure with increasing urbanisation. - Landscape and Urban Planning 180: 54-59. https://doi.org/10.1016/j.landurbplan.2018.08.010

Ewers, R. M. \& Didham, R. K. (2006): Continuous response functions for quantifying the strength of edge effects. - Journal of Applied Ecology 43(3): 527-536. https://doi. org/10.1111/j.1365-2664.2006.01151.x

Fenoglio, M. S., Rossetti, M. R. \& Videla, M. (2020): Negative effects of urbanisation on terrestrial arthropod communities: A meta-analysis. - Global Ecology and Biogeography 29: 1412-1429. https://doi.org/10.1111/geb.13107

Ferrante, M., González, E. \& Lövei, G. L. (2017): Predators do not spill over from forest fragments to maise fields in a landscape mosaic in central Argentina. - Ecology and Evolution 7(19): 7699-7707. https://doi.org/10.1002/ece3.3247

Gayer, C., Lövei, G. L., Magura, T., Dieterich, M. \& Batáry, P. (2019): Carabid functional diversity is enhanced by conventional flowering fields, organic winter cereals and edge habitats. - Agriculture, Ecosystems \& Environment 284: 106579. https://doi. org/10.1016/j.agee.2019.106579

Gobi, M. \& Fontaneto, D. (2008): Biodiversity of ground beetles (Coleoptera: Carabidae) in different habitats of the Italian Po lowland. - Agriculture, Ecosystems \& Environment 127(3-4): 273-276. https://doi.org/10.1016/j.agee.2008.04.011

Hardt, E., Pereira-Silva, E. F. L., Santos, R. F. Dos, Tamashiro, J. Y., Ragazzi, S. \& Lins, D. B. d. S. (2013): The influence of natural and anthropogenic landscapes on edge effects. - Landscape and Urban Planning 120: 59-69. https://doi.org/10.1016/j.landurbplan.2013.08.014

Harper, K. A., Drapeau, P., Lesieur, D. \& Bergeron, Y. (2014): Forest structure and composition at fire edges of different ages: Evidence of persistent structural features on 
the landscape. - Forest Ecology and Management 314: 131-140. https://doi.org/10.1016/j. foreco.2013.12.009

Harper, K. A., Macdonald, S. E., Burton, P. J., Chen, J., Brosofske, K. D., Saunders, S. C., Euskirchen, E. S., Roberts, D., Jaiteh, M. S. \& Esseen, P. A. (2005): Edge influence on forest structure and composition in fragmented landscapes. - Conservation Biology 19(3): 768-782. https://doi.org/10.1111/j.1523-1739.2005.00045.x

Harper, K. A., Macdonald, S. E., Mayerhofer, M. S., Biswas, S. R., Esseen, P.-A., Hylander, K., Stewart, K. J., Mallik, A. U., Drapeau, P., Jonsson, B.-G., Lesieur, D., Kouki, J. \& Bergeron, Y. (2015): Edge influence on vegetation at natural and anthropogenic edges of boreal forests in Canada and Fennoscandia. - Journal of Ecology 103(3): 550-562. https://doi.org/10.1111/1365-2745.12398

Holland J. (2002): The agroecology of carabid beetles. - Intercept Publishers, Andover, 356 pp. Homburg, K., Homburg, N., Schäfer, F., Schuldt, A. \& Assmann, T. (2014): Carabids.org - a dynamic online database of ground beetle species traits (Coleoptera, Carabidae). - Insect Conservation and Diversity 7(3): 195-205. https://doi.org/10.1111/icad.12045

Jelaska, L. Š. \& Durbešić, P. (2009): Comparison of the body size and wing form of carabid species (coleoptera: Carabidae) between isolated and continuous forest habitats. Annales de la Societe Entomologique de France 45(3): 327-338. https://doi.org/10.1080/00 379271.2009.10697618

Jetz, W., Carbone, C., Fulford, J. \& Brown, J. H. (2004): The scaling of animal space use. Science 306(5694): 266-268. https://doi.org/10.1126/science.1102138

Jowett, K., Milne, A. E., Metcalfe, H., Hassall, K. L., Potts, S. G., Senapathi, D. \& StorKEY, J. (2019): Species matter when considering landscape effects on carabid distributions. - Agriculture, Ecosystems \& Environment 285: 106631. https://doi.org/https://doi. org/10.1016/j.agee.2019.106631

Kędzior, R., Szwalec, A., Mundąa, P. \& Skalski, T. (2020): Ground beetle (Coleoptera, Carabidae) life history traits as indicators of habitat recovering processes in postindustrial areas. - Ecological Engineering 142: 105615. https://doi.org/https://doi. org/10.1016/j.ecoleng.2019.105615

Kingsolver, J. G. \& Huey, R. B. (2008): Size, temperature, and fitness: three rules. - Evolutionary Ecology Research 10(2): 251-268.

Knapp, M., Seidl, M., Knappová, J., MaceK, M. \& Saska, P. (2019): Temporal changes in the spatial distribution of carabid beetles around arable field-woodlot boundaries. - Scientific Reports 9(1): 8967. https://doi.org/10.1038/s41598-019-45378-7

Koivula, M., HyyryläInen, V. \& Soininen, E. (2004): Carabid beetles (Coleoptera: Carabidae) at forest-farmland edges in southern Finland. - Journal of Insect Conservation 8(4): 297-309. https://doi.org/10.1007/s10841-004-0296-9

Kotze, D. J. \& O'Hara, R. B. (2003): Species decline - but why? Explanations of carabid beetle (Coleoptera, Carabidae) declines in Europe. - Oecologia 135(1): 138-148. https:// doi.org/10.1007/s00442-002-1174-3

Kromp, B. (1999): Carabid beetles in sustainable agriculture: a review on pest control efficacy, cultivation impacts and enhancement. - Agriculture, Ecosystems E Environment 74(1): 187-228. https://doi.org/10.1016/S0167-8809(99)00037-7

Lacasella, F., Gratton, C., Felici, S. De, Isaia, M., Zapparoli, M., Marta, S. \& Sbordoni, V. (2015): Asymmetrical responses of forest and 'beyond edge' arthropod communities across a forest-grassland ecotone. - Biodiversity and Conservation 24(3): 447-465. https://doi.org/10.1007/s10531-014-0825-0 
Leslie, T. W., Biddinger, D. J., Rohr, J. R., Hulting, A. G., Mortensen, D. A. \& Fleischer, S. J. (2014): Examining shifts in Carabidae assemblages across a forest-agriculture ecotone. - Environmental Entomology 43(1): 18-28. https://doi.org/10.1603/EN13099

LöveI, G. L. \& MAgurA, T. (2006): Body size changes in ground beetle assemblages - A reanalysis of Braun et al. (2004)'s data. - Ecological Entomology 31(5): 411-414. https://doi. org/10.1111/j.1365-2311.2006.00794.x

Lövei, G. L. \& Sunderland, K. D. (1996): Ecology and behavior of ground beetles (Coleoptera: Carabidae). - Annual Review of Entomology 41: 231-256. https://doi.org/10.1146/ annurev.en.41.010196.001311

Magura, T. (2002): Carabids and forest edge: Spatial pattern and edge effect. - Forest Ecology and Management 157(1-3): 23-37. https://doi.org/10.1016/S0378-1127(00)00654-X

MAGurA, T. (2017): Ignoring functional and phylogenetic features masks the edge influence on ground beetle diversity across forest-grassland gradient. - Forest Ecology and Management 384: 371-377. https://doi.org/10.1016/j.foreco.2016.10.056

Magura, T., Elek, Z. \& Tóthmérész, B. (2002): Impacts of non-native spruce reforestation on ground beetles. - European Journal of Soil Biology 38(3-4): 291-295. https://doi. org/10.1016/S1164-5563(02)01162-7

Magura, T., Ferrante, M. \& Lövei, G. L. (2020): Only habitat specialists become smaller with advancing urbanisation. - Global Ecology and Biogeography 29(11): 1978-1987. https://doi.org/10.1111/geb.13168

Magura, T. \& Lövei, G. L. (2019): Environmental filtering is the main assembly rule of ground beetles in the forest and its edge but not in the adjacent grassland. - Insect Science 26(1): 154-163. https://doi.org/10.1111/1744-7917.12504

Magura, T. \& Lövei, G. L. (2020a): Consequences of urban living: Urbanisation and ground beetles. - Current Landscape Ecology Reports 5(4): in press. https://doi.org/10.1007/ s40823-020-00060-x

Magura, T. \& LöveI, G. L. (2020b): The permeability of natural versus anthropogenic forest edges modulates the abundance of ground beetles of different dispersal power and habitat affinity. - Diversity 12(9): 320. https://doi.org/10.3390/d12090320

Magura, T., Lövei, G. L. \& Tóthmérész, B. (2018): Conversion from environmental filtering to randomness as assembly rule of ground beetle assemblages along an urbanisation gradient. - Scientific Reports 8(1): 16992. https://doi.org/10.1038/s41598-018-35293-8

Magura, T., Lövei, G. L. \& Tóthmérész, B. (2010): Does urbanisation decrease diversity in ground beetle (Carabidae) assemblages? - Global Ecology and Biogeography 19(1): 16-26. https://doi.org/10.1111/j.1466-8238.2009.00499.x

Magura, T., Lövei, G. L. \& Tóthmérész, B. (2017): Edge responses are different in edges under natural versus anthropogenic influence: a meta-analysis using ground beetles. - Ecology and Evolution 7(3): 1009-1017. https://doi.org/10.1002/ece3.2722

Magura, T., Lövei, G. L. \& Tóthmérész, B. (2019): Various edge response of ground beetles in edges under natural versus anthropogenic influence: A meta-analysis using life-history traits. - Acta Zoologica Academiae Scientiarum Hungaricae 65(Suppl.): 3-20. https://doi.org/10.17109/AZH.65.Suppl.3.2019

Murcia, C. (1995): Edge effects in fragmented forests: implications for conservation. - Trends in Ecology and Evolution 10(2): 58-62. https://doi.org/10.1016/S0169-5347(00)88977-6

Nagy, D. D., Magura, T., Horváth, R., Debnár, Z. \& Tóthmérész, B. (2018): Arthropod assemblages and functional responses along an urbanisation gradient: a trait-based multi-taxa approach. - Urban Forestry \& Urban Greening 30: 157-168. https://doi. org/10.1016/j.ufug.2018.01.002 
Ohlberger, J. (2013): Climate warming and ectotherm body size - from individual physiology to community ecology. - Functional Ecology 27(4): 991-1001. https://doi. org/10.1111/1365-2435.12098

Paillet, Y., Bergès, L., HJältén, J., Ódor, P., Avon, C., Bernhardt-Römermann, M., Bijlsma, R.-J., Bruyn, L. De, Fuhr, M., Grandin, U., Kanka, R., Lundin, L., Luque, S., Magura, T., Matesanz, S., Mészáros, I., Sebastia, M.-T., Schmidt, W., Standovár, T., Tóthmérész, B., Uotila, A., Valladares, F., Vellak, K. \& Virtanen, R. (2010): Biodiversity differences between managed and unmanaged forests: Meta-analysis of species richness in Europe. - Conservation Biology 24(1): 101-112. https://doi.org/10.1111/ j.1523-1739.2009.01399.x

Petchey, O. L. \& Belgrano, A. (2010): Body-size distributions and size-spectra: universal indicators of ecological status? - Biology Letters 6(4): 434-437. https://doi.org/10.1098/ rsbl.2010.0240

Peters, R. H. (1983): The ecological implications of body size. - Cambridge University Press, Cambridge, 329 pp.

Peyras, M., Vespa, N. I., Belloce, M. I. \& Zurita, G. A. (2013): Quantifying edge effects: The role of habitat contrast and species specialisation. - Journal of Insect Conservation 17(4): 807-820. https://doi.org/10.1007/s10841-013-9563-y

R Core TeAm. (2017): R: A language and environment for statistical computing. - R Foundation for Statistical Computing: Vienna, Austria. https://doi.org/http://www.R-project.org

Ribera, I., Dolédec, S., Downie, I. S. \& Foster, G. N. (2001): Effect of land disturbance and stress on species traits of ground beetle assemblages. - Ecology 82: 1112-1129. https:// doi.org/10.1890/0012-9658(2001)082[1112:EOLDAS]2.0.CO;2

Ries, L., Fletcher, R. J., Battin, J. \& Sisk, T. D. (2004): Ecological responses to habitat edges: Mechanisms, models, and variability explained. - Annual Review of Ecology Evolution and Systematics 35: 491-522. https://doi.org/10.1146/annurev.ecolsys.35.112202.130148

Ries, L. \& Sisk, T. D. (2004): A predictive model of edge effects. - Ecology 85(11): 2917-2926. https://doi.org/10.1890/03-8021

Roume, A., Deconchat, M., Raison, L., Balent, G. \& Ouin, A. (2011): Edge effects on ground beetles at the woodlot-field interface are short-range and asymmetrical. - Agricultural and Forest Entomology 13(4): 395-403. https://doi.org/10.1111/j.1461-9563.2011.00534.x

Samways, M. J. (2007): Insect conservation: A synthetic management approach. - Annual Review of Entomology 52(1): 465-487. https://doi.org/10.1146/annurev.ento.52.110405.091317

Smedt, P. De, Baeten, L., Proesmans, W., Poel, S. Van de, Keer, J. Van, Giffard, B., Martin, L., Vanhulle, R., Brunet, J., Cousins, S. A. O., Decoce, G., Deconchat, M., Diekmann, M., Gallet-Moron, E., Roux, V. Le, Litra, J., Valdés, A., Wulf, M., Andrieu, E., Hermy, M., Bonte, D. \& Verheyen, K. (2019): Strength of forest edge effects on litterdwelling macro-arthropods across Europe is influenced by forest age and edge properties. - Diversity and Distributions 25(6): 963-974. https://doi.org/10.1111/ddi.12909

Spake, R., Barsoum, N., Newton, A. C. \& Doncaster, C. P. (2016): Drivers of the composition and diversity of carabid functional traits in UK coniferous plantations. - Forest Ecology and Management 359: 300-308. https://doi.org/10.1016/j.foreco.2015.10.008

Strayer, D., Power, M., WF, F., STA, P. \& J, B. (2003): A classification of ecological boundaries. - BioScience 53(8): 723-729. https://doi.org/10.1641/0006-3568(2003)053[0723:AC $\mathrm{OEB}] 2.0 . \mathrm{CO} ; 2$

Tscharntke, T., Tylianakis, J. M., Rand, T. A., Didham, R. K., Fahrig, L., Batáry, P., Bengtsson, J., Clough, Y., Crist, T. O., Dormann, C. F., Ewers, R. M., Fründ, J., Holt, R. D., Holzschuh, A., Klein, A. M., Kleijn, D., Kremen, C., Landis, D. A., Laurance, W., 
Lindenmayer, D., Scherber, C., Sodhi, N., Steffan-Dewenter, I., Thies, C., Putten, W. H. van DER \& WestPhal, C. (2012): Landscape moderation of biodiversity patterns and processes - eight hypotheses. - Biological Reviews 87(3): 661-685. https://doi. org/10.1111/j.1469-185X.2011.00216.x

Turner, M. G. \& GARDNer, R. H. (2015): Landscape ecology in theory and practice. Pattern and process. - Springer-Verlag, New York, $482 \mathrm{pp}$.

Viechtbauer, W. (2010): Conducting meta-analyses in R with the metafor package. - Journal of Statistical Software 36(3): 1-48. https://doi.org/10.1103/PhysRevB.91.121108

Woodward, G., Ebenman, B., Emmerson, M., Montoya, J. M., Olesen, J. M., Valido, A. \& Warren, P. H. (2005): Body size in ecological networks. - Trends in Ecology E Evolution 20(7): 402-409. https://doi.org/10.1016/j.tree.2005.04.005

Received August 30, 2020, accepted October 27, 2020, published December 28, 2020 


\section{APPENDIX}

Table S1. Publications used in the meta-analyses, which reported mean values of abundances, standard deviation, and sample size for both the forest interior and the forest edge.

\begin{tabular}{|c|c|c|c|}
\hline Edge type & Human disturbance & Country & Reference \\
\hline natural & none & Hungary & ELEK \& TóthMérÉSz 2010 \\
\hline natural & none & Italy & LACASELLA et al. 2015 \\
\hline natural & none & Hungary & MAGURA 2002 \\
\hline natural & none & Hungary & MAGURA \& TóthMÉRÉSz 1997 \\
\hline natural & none & Hungary & MAGURA \& TóthMÉRÉSz 1998 \\
\hline natural & none & Hungary & Magura et al. 2000 \\
\hline natural & none & Hungary & Magura et al. 2001 \\
\hline natural & none & Hungary & Magura et al. 2002 \\
\hline natural & none & Romania & MÁthé 2006 \\
\hline natural & none & Hungary & Molnár et al. 2001 \\
\hline natural & none & Hungary & TóTHмÉRÉsz et al. 2014 \\
\hline disturbed & agriculture & UK & BEDFORD \& UsHer 1994 \\
\hline disturbed & agriculture & New Zealand & EWERs 2008 \\
\hline disturbed & agriculture & Japan & Kagawa \& MaEto 2009 \\
\hline disturbed & agriculture & Japan & Kagawa \& MaEto 2014 \\
\hline disturbed & agriculture & South Africa & Kotze \& Samways 1999 \\
\hline disturbed & agriculture & Poland & SKLODOWSKI 1999 \\
\hline disturbed & agriculture & Spain & TABOADA et al. 2004 \\
\hline disturbed & agriculture & China & Yu et al. 2007 \\
\hline disturbed & forestry & Australia & Davies \& Margules 1998 \\
\hline disturbed & forestry & Belgium & Gaublomme et al. 2013 \\
\hline disturbed & forestry & USA & Halaj et al. 2008 \\
\hline disturbed & forestry & Finland & HeLiöLÄ et al. 2001 \\
\hline disturbed & forestry & Canada & Lemieux \& Lindgren 2004 \\
\hline disturbed & forestry & Canada & Phillips et al. 2006 \\
\hline disturbed & forestry & Canada & SPENCE et al. 1996 \\
\hline disturbed & forestry & USA & ULYSHEN et al. 2006 \\
\hline disturbed & forestry & China & Yu et al. 2009 \\
\hline disturbed & urbanisation & Belgium & Gaublomme et al. 2008 \\
\hline disturbed & urbanisation & Belgium & Gaublomme et al. 2013 \\
\hline disturbed & urbanisation & USA & Silverman et al. 2008 \\
\hline
\end{tabular}




\section{References in Table S1}

Bedford, S. E. \& Usher, M. B. (1994): Distribution of arthropod species across the margins of farm woodlands. - Agriculture, Ecosystems \& Environment 48: 295-305. https://doi. org/10.1016/0167-8809(94)90111-2

Davies, K. F. \& Margules, C. R. (1998): Effects of habitat fragmentation on carabid beetles: experimental evidence. - Journal of Animal Ecology 67: 460-471. https://doi. org/10.1046/j.1365-2656.1998.00210.x

ELEK, Z. \& TóthméRÉsz, B. (2010): Carabid beetles among grassland-forest edge-beech forest habitats in Northern Hungary. - Community Ecology 11: 211-216. https://doi. org/10.1556/ComEc.11.2010.2.9

Ewers, R. M. (2008): Spatio-temporal variation in mortality rates of Mecodema spp. (Coleoptera: Carabidae) across a forest-grassland edge in New Zealand. - Insect Conservation and Diversity 1: 40-47. https://doi.org/10.1111/j.1752-4598.2007.00006.x

Gaublomme, E., Hendrickx, F., Dhuyvetter, H. \& Desender, K. (2008): The effects of forest patch size and matrix type on changes in carabid beetle assemblages in an urbanised landscape. - Biological Conservation 141: 2585-2596. https://doi.org/10.1016/j. biocon.2008.07.022

Gaublomme, E., Maebe, K., Van Doninck, K., Dhuyvetter, H., Li, X., Desender, K. \& HeNDRICKX, F. (2013): Loss of genetic diversity and increased genetic structuring in response to forest area reduction in a ground dwelling insect: a case study of the flightless carabid beetle Carabus problematicus (Coleoptera, Carabidae). - Insect Conservation and Diversity 6: 473-482. https://doi.org/10.1111/icad.12002

Halaj, J., Halpern, C. B. \& Yi, H. (2008): Responses of litter-dwelling spiders and carabid beetles to varying levels and patterns of green-tree retention. - Forest Ecology and Management 255: 887-900. https://doi.org/10.1016/j.foreco.2007.09.083

Heliölä, J., Koivula, M. \& Niemelë, J. (2001): Distribution of carabid beetles (Coleoptera, Carabidae) across a boreal forest-clearcut ecotone. - Conservation Biology 15: 370-377. https://doi.org/10.1046/j.1523-1739.2001.015002370.x

Kagawa, Y. \& MaEto, K. (2009): Spatial population structure of the predatory ground beetle Carabus yaconinus (Coleoptera: Carabidae) in the mixed farmland-woodland satoyama landscape of Japan. - European Journal of Entomology 106: 385-391. https://doi. org/10.14411/eje.2009.049

Kagawa, Y. \& Maeto, K. (2014): Ground beetle (Coleoptera: Carabidae) assemblages associated with a satoyama landscape in Japan: the effects of soil moisture, weed height, and distance from woodlands. - Applied Entomology and Zoology 49: 429-436. https:// doi.org/10.1007/s13355-014-0266-y

Kotze, D. J. \& Samways, M. J. (1999): Invertebrate conservation at the interface between the grassland matrix and natural Afromontane forest fragments. - Biodiversity and Conservation 8: 1339-1363. https://doi.org/10.1023/A:1008945302029

Lacasella, F., Gratton, C., De Felici, S., Isaia, M., Zapparoli, M., Marta, S. \& Sbordoni, V. (2015): Asymmetrical responses of forest and "beyond edge" arthropod communities across a forest-grassland ecotone. - Biodiversity and Conservation 24: 447-465. https://doi.org/10.1007/s10531-014-0825-0

Lemieux, J. P. \& Lindgren, B. S. (2004): Ground beetle responses to patch retention harvesting in high elevation forests of British Columbia. - Ecography 27: 557-566. https://doi. org/10.1111/j.0906-7590.2004.03888.x 
Magura, T. (2002): Carabids and forest edge: spatial pattern and edge effect. - Forest Ecology and Management 157: 23-37. https://doi.org/10.1016/S0378-1127(00)00654-X

Magura, T. \& Tóthmérész, B. (1997): Testing edge effect on carabid assemblages in an oak-hornbeam forest. - Acta Zoologica Academiae Scientiarum Hungaricae 43: 303-312.

MagurA, T. \& Tóthmérész, B. (1998): Edge effect on carabids in an oak-hornbeam forest at the Aggtelek National Park (Hungary). - Acta Phytopathologica et Entomologica Hungarica 33: 379-387.

Magura, T., Tóthmérész, B. \& Bordán, Zs. (2002): Carabids in an oak-hornbeam forest: testing the edge effect hypothesis. - Acta Biologica Debrecina 24: 55-72.

Magura, T., Tóthmérész, B. \& Molnár, T. (2000): Spatial distribution of carabids along grass-forest transects. - Acta Zoologica Academiae Scientiarum Hungaricae 46: 1-17.

Magura, T., Tóthmérész, B. \& Molnár, T. (2001): Forest edge and diversity: carabids along forest-grassland transects. - Biodiversity and Conservation 10: 287-300. https://doi. org/10.1023/A:1008967230493

MÁтнÉ, I. (2006): Forest edge and carabid diversity in a Carpathian beech forest. - Community Ecology 7: 91-97. https://doi.org/10.1556/ComEc.7.2006.1.9

Molnár, T., Magura, T., Tóthmérész, B. \& Elek, Z. (2001): Ground beetles (Carabidae) and edge effect in oak-hornbeam forest and grassland transects. - European Journal of Soil Biology 37: 297-300. https://doi.org/10.1016/S1164-5563(01)01103-7

Phillips, I. D., Cobb, T. P., Spence, J. R. \& Brigham, R. M. (2006): Salvage logging, edge effects, and carabid beetles: Connections to conservation and sustainable forest management. - Environmental Entomology 35: 950-957. https://doi.org/10.1603/0046-225X-35.4.950

Silverman, B., Horn, D. J., Purrington, F. F. \& Gandhi, K. J. K. (2008): Oil pipeline corridor through an intact forest alters ground beetle (Coleoptera: Carabidae) assemblages in Southeastern Ohio. - Environmental Entomology 37: 725-733. https://doi. org/10.1093/ee/37.3.725

SкLороwsкi, J. (1999): Movement of selected carabid species (Col. Carabidae) through a pine forest-fallow ecotone. - Folia Forestalia Polonica 41: 5-23.

Spence, J. R., Langor, D. W., Niemelä, J., Cárcamo, H. A. \& Currie, C. R. (1996): Northern forestry and carabids: the case for concern about old-growth species. - Annales Zoologici Fennici 33: 173-184.

Taboada, A., Kotze, D. J. \& Salgado, J. M. (2004): Carabid beetle occurrence at the edges of oak and beech forests in NW Spain. - European Journal of Entomology 101: 555-563. https://doi.org/10.14411/eje.2004.079

Tóthmérész, B., Nagy, D. D., Mizser, S., Bogyó, D. \& Magura, T. (2014): Edge effects on ground-dwelling beetles (Carabidae and Staphylinidae) in oak forest-forest edgegrassland habitats in Hungary. - European Journal of Entomology 111: 686-691. https:// doi.org/10.14411/eje.2014.091

Ulyshen, M. D., Hanula, J. L., Scott, H., Kilgo, J. C. \& Moorman, C. E. (2006): The response of ground beetles (Coleoptera: Carabidae) to selection cutting in a South Carolina bottomland hardwood forest. - Biodiversity and Conservation 15: 261-274. https:// doi.org/10.1007/978-1-4020-5204-0_16

Yu, X-D., Lou, T-H., Zhou, H-Z. \& YANG, J. (2007): Distribution of carabid beetles (Coleoptera: Carabidae) across a forest-grassland ecotone in Southwestern China. - Environmental Entomology 36: 348-355. https://doi.org/10.1093/ee/36.2.348

Yu, X-D., Lou, T-H. \& ZHou, H-Z. (2009): Distribution of carabid beetles (Coleoptera: Carabidae) across ecotones between regenerating and mature forests in Southwestern China. - Environmental Entomology 38: 1053-1060. https://doi.org/10.1603/022.038.0412 
Table S2. Lists of species from the 30 published papers used in the meta-analyses, and their body sizes $(\mathrm{L}=$ large, $\mathrm{M}=$ medium, $\mathrm{S}=$ small), habitat affinity $(\mathrm{F}=$ forest, $\mathrm{G}=$ generalist, $\mathrm{O}=$ open-habitat $)$, wing form $(\mathrm{B}=$ brachypterous, $\mathrm{D}=$ dimorphic, $\mathrm{M}=$ macropterous) and breeding type $(\mathrm{AB}=$ autumn breeder, $\mathrm{SB}=$ spring breeder, $\mathrm{SB} \& \mathrm{AB}=$ spring and autumn breeder). NA = not available

\begin{tabular}{|c|c|c|c|c|}
\hline Species & Body size & Habitat affinity & Wing form & Breeding \\
\hline Abax carinatus & $\mathrm{L}$ & G & B & $\mathrm{AB}$ \\
\hline Abax ovalis & $\mathrm{L}$ & $\mathrm{F}$ & B & SB \\
\hline Abax parallelepipedus & $\mathrm{L}$ & G & B & SB \& $A B$ \\
\hline Abax parallelus & $\mathrm{L}$ & $\mathrm{F}$ & B & SB \\
\hline Abax schueppeli & $\mathrm{L}$ & F & B & NA \\
\hline Acupalpus sp. & $S$ & NA & NA & NA \\
\hline Acupalpus testaceus & $S$ & $\mathrm{O}$ & M & NA \\
\hline Agonum aeruginosum & S & G & M & SB \\
\hline Agonum afrum & $S$ & G & M & SB \\
\hline Agonum decorum & S & G & M & SB \\
\hline Agonum duftschmidi & $S$ & G & M & SB \\
\hline Amara aenea & $S$ & $\mathrm{O}$ & M & SB \\
\hline Amara anthobia & $S$ & G & M & SB \\
\hline Amara convexior & $S$ & G & M & SB \\
\hline Amara curta & $S$ & $\mathrm{O}$ & M & SB \\
\hline Amara equestris & M & $\mathrm{O}$ & M & $\mathrm{AB}$ \\
\hline Amara eurynota & M & $\mathrm{O}$ & M & $A B$ \\
\hline Amara familiaris & S & $\mathrm{O}$ & M & SB \\
\hline Amara macronata & M & G & M & $\mathrm{AB}$ \\
\hline Amara montivaga & $S$ & $\mathrm{O}$ & M & SB \\
\hline Amara nitida & $S$ & $\mathrm{O}$ & M & SB \\
\hline Amara obesa & M & $\mathrm{O}$ & $\mathrm{D}$ & $\mathrm{AB}$ \\
\hline Amara ovata & S & $\mathrm{F}$ & M & SB \\
\hline Amara saphyrea & M & F & M & SB \\
\hline Amara sicula & M & $\mathrm{O}$ & B & NA \\
\hline Anisodactylus binotatus & M & $\mathrm{O}$ & M & SB \\
\hline Anisodactylus punctatipennis & M & G & NA & SB \\
\hline Aptinus bombarda & M & $\mathrm{F}$ & B & SB \\
\hline Aristochroa gratiosa & $\mathrm{L}$ & $\mathrm{F}$ & NA & NA \\
\hline Asaphidion flavipes & $S$ & $\mathrm{O}$ & M & SB \\
\hline
\end{tabular}


Table S2 (continued)

\begin{tabular}{|c|c|c|c|c|}
\hline Species & Body size & Habitat affinity & Wing form & Breeding \\
\hline Badister bullatus & $S$ & G & M & SB \\
\hline Badister lacertosus & $S$ & G & M & SB \\
\hline Badister meridionalis & $S$ & $\mathrm{O}$ & M & SB \\
\hline Bembidion grapii & $S$ & $\mathrm{O}$ & $\mathrm{D}$ & SB \\
\hline Bembidion guttula & $S$ & G & $\mathrm{D}$ & SB \\
\hline Bembidion lampros & $S$ & G & $\mathrm{D}$ & SB \\
\hline Bembidion oblongulum & $S$ & $\mathrm{~F}$ & B & NA \\
\hline Bembidion tetracolum & $S$ & G & $\mathrm{D}$ & SB \\
\hline Brachinus alternans & $\mathrm{L}$ & G & M & SB \\
\hline Calathus advena & M & $\mathrm{F}$ & M & $\mathrm{AB}$ \\
\hline Calathus cinctus & $S$ & $\mathrm{O}$ & $\mathrm{D}$ & $\mathrm{AB}$ \\
\hline Calathus fuscipes & M & $\mathrm{O}$ & B & $\mathrm{AB}$ \\
\hline Calathus ingratus & M & F & $\mathrm{D}$ & SB \\
\hline Calathus melanocephalus & $S$ & $\mathrm{O}$ & $\mathrm{D}$ & $\mathrm{AB}$ \\
\hline Calosoma chinense & $\mathrm{L}$ & G & M & $\mathrm{AB}$ \\
\hline Calosoma davidis & $\mathrm{L}$ & $\mathrm{O}$ & NA & NA \\
\hline Calosoma tepidum & $\mathrm{L}$ & $\mathrm{O}$ & M & SB \\
\hline Carabus arvensis & $\mathrm{L}$ & G & B & SB \\
\hline Carabus auronitens & $\mathrm{L}$ & $\mathrm{F}$ & B & SB \\
\hline Carabus cancellatus & $\mathrm{L}$ & G & B & SB \\
\hline Carabus convexus & $\mathrm{L}$ & G & B & SB \\
\hline Carabus coriaceus & $\mathrm{L}$ & F & B & $\mathrm{AB}$ \\
\hline Carabus glabratus & $\mathrm{L}$ & $\mathrm{F}$ & M & $\mathrm{AB}$ \\
\hline Carabus granulatus & $\mathrm{L}$ & G & $\mathrm{D}$ & SB \\
\hline Carabus hampei & $\mathrm{L}$ & G & B & NA \\
\hline Carabus hortensis & $\mathrm{L}$ & $\mathrm{F}$ & B & $\mathrm{AB}$ \\
\hline Carabus intricatus & $\mathrm{L}$ & F & B & SB \\
\hline Carabus limbatus & $\mathrm{L}$ & $\mathrm{F}$ & B & SB \\
\hline Carabus lineatus & $\mathrm{L}$ & F & B & NA \\
\hline Carabus linnei & $\mathrm{L}$ & F & B & NA \\
\hline Carabus marginalis & $\mathrm{L}$ & $\mathrm{F}$ & B & NA \\
\hline Carabus montivagus & $\mathrm{L}$ & G & B & $\mathrm{AB}$ \\
\hline Carabus nemoralis & $\mathrm{L}$ & G & B & SB \\
\hline
\end{tabular}


Table S2 (continued)

\begin{tabular}{|c|c|c|c|c|}
\hline Species & Body size & Habitat affinity & Wing form & Breeding \\
\hline Carabus obsoletus & $\mathrm{L}$ & $\mathrm{F}$ & B & NA \\
\hline Carabus problematicus & $\mathrm{L}$ & $\mathrm{F}$ & B & $\mathrm{AB}$ \\
\hline Carabus shamaevi & $\mathrm{L}$ & G & NA & NA \\
\hline Carabus sylvosus & $\mathrm{L}$ & G & B & $\mathrm{AB}$ \\
\hline Carabus taedatus & $\mathrm{L}$ & $\mathrm{O}$ & B & NA \\
\hline Carabus ullrichii & $\mathrm{L}$ & G & B & SB \\
\hline Carabus variolosus & $\mathrm{L}$ & $\mathrm{F}$ & B & SB \\
\hline Carabus violaceus & $\mathrm{L}$ & $\mathrm{F}$ & B & SB \\
\hline Carabus yaconinus & $\mathrm{L}$ & G & B & SB \\
\hline Carabus zawadszkii & $\mathrm{L}$ & $\mathrm{F}$ & B & NA \\
\hline Chlaenius abstersus & $\mathrm{L}$ & G & M & NA \\
\hline Chlaenius aestivus & $\mathrm{L}$ & $\mathrm{F}$ & $\mathrm{D}$ & SB \\
\hline Chlaenius erythropus & $\mathrm{L}$ & $\mathrm{F}$ & M & $\mathrm{SB}$ \\
\hline Chlaenius naeviger & $\mathrm{L}$ & G & M & SB \\
\hline Chlaenius sericimicans & $\mathrm{L}$ & G & NA & SB \\
\hline Cicindela germanica & M & $\mathrm{O}$ & M & $\mathrm{AB}$ \\
\hline Cicindela longilabris & $\mathrm{L}$ & $\mathrm{O}$ & M & SB \& AB \\
\hline Clivina bipustulata & S & $\mathrm{O}$ & M & SB \\
\hline Clivina fossor & S & $\mathrm{O}$ & $\mathrm{D}$ & SB \\
\hline Clivina rubicunda & $S$ & NA & M & NA \\
\hline Cophosomorpha angulicollis & $\mathrm{L}$ & NA & NA & NA \\
\hline Cychrus attenuatus & $\mathrm{L}$ & $\mathrm{F}$ & $\mathrm{B}$ & $\mathrm{AB}$ \\
\hline Cychrus caraboides & $\mathrm{L}$ & $\mathrm{F}$ & B & $\mathrm{AB}$ \\
\hline Cychrus italicus & $\mathrm{L}$ & F & B & $\mathrm{AB}$ \\
\hline Cychrus okamotoi & $\mathrm{L}$ & $\mathrm{F}$ & B & NA \\
\hline Cychrus spinicollis & $\mathrm{L}$ & $\mathrm{F}$ & B & NA \\
\hline Cychrus tuberculatus & $\mathrm{L}$ & $\mathrm{F}$ & B & NA \\
\hline Cyclotrachelus brevoorti & $\mathrm{L}$ & $\mathrm{F}$ & B & NA \\
\hline Cymindis axillaris & M & $\mathrm{O}$ & $\mathrm{D}$ & NA \\
\hline Cymindis cingulata & $S$ & G & $\mathrm{M}$ & NA \\
\hline Cymindis etrusca & M & $\mathrm{O}$ & NA & NA \\
\hline Dicaelus dilatatus & $\mathrm{L}$ & G & $\mathrm{B}$ & SB \\
\hline Dicaelus elongatus & $\mathrm{L}$ & G & B & SB \\
\hline
\end{tabular}


Table S2 (continued)

\begin{tabular}{|c|c|c|c|c|}
\hline Species & Body size & Habitat affinity & Wing form & Breeding \\
\hline Dicheirotrichus cognatus & $S$ & $\mathrm{O}$ & M & SB \\
\hline Diplocheila assimilis & $\mathrm{L}$ & $\mathrm{F}$ & M & SB \\
\hline Dyschirius globosus & S & G & B & SB \\
\hline Elaphrus clairvillei & $S$ & G & M & SB \\
\hline Galerita bicolor & $\mathrm{L}$ & G & M & SB \\
\hline Galerita sp. & $\mathrm{L}$ & G & M & SB \\
\hline Harpalus affinis & M & $\mathrm{O}$ & M & $\mathrm{SB} \& \mathrm{AB}$ \\
\hline Harpalus attenuatus & $S$ & $\mathrm{O}$ & M & NA \\
\hline Harpalus chalcentus & $\mathrm{L}$ & $\mathrm{O}$ & M & SB \\
\hline Harpalus griseus & M & G & M & $\mathrm{AB}$ \\
\hline Harpalus latus & M & G & M & SB \& AB \\
\hline Harpalus pensylvanicus & $\mathrm{L}$ & $\mathrm{O}$ & M & $\mathrm{AB}$ \\
\hline Harpalus rubripes & M & $\mathrm{O}$ & M & $\mathrm{SB} \& \mathrm{AB}$ \\
\hline Harpalus serripes & M & $\mathrm{O}$ & M & SB \\
\hline Harpalus sinicus & $\mathrm{L}$ & G & M & $\mathrm{AB}$ \\
\hline Harpalus sulphuripes & $S$ & $\mathrm{O}$ & NA & NA \\
\hline Harpalus tardus & M & $\mathrm{O}$ & M & SB \\
\hline Harpalus tridens & M & G & M & $\mathrm{AB}$ \\
\hline Hystrichopus praedator & $\mathrm{L}$ & NA & NA & NA \\
\hline Hystrichopus vigilans & $\mathrm{L}$ & NA & NA & NA \\
\hline Laemostenus latialis & $\mathrm{L}$ & $\mathrm{F}$ & NA & NA \\
\hline Laemostenus terricola & $\mathrm{L}$ & G & $\mathrm{B}$ & $\mathrm{SB}$ \\
\hline Lebia chlorocephala & $S$ & $\mathrm{O}$ & M & $\mathrm{SB}$ \\
\hline Lebia cyanocephala & $S$ & $\mathrm{O}$ & M & SB \\
\hline Leistus ferrugineus & S & G & M & $\mathrm{AB}$ \\
\hline Leistus fulvibarbis & $S$ & $\mathrm{~F}$ & M & $\mathrm{AB}$ \\
\hline Leistus piceus & S & G & B & $\mathrm{AB}$ \\
\hline Leistus rufomarginatus & S & $\mathrm{F}$ & $\mathrm{B}$ & $\mathrm{AB}$ \\
\hline Leistus spinibarbis & M & $\mathrm{O}$ & M & $\mathrm{AB}$ \\
\hline Lesticus magnus & $\mathrm{L}$ & G & M & $\mathrm{SB}$ \\
\hline Licinus depressus & M & $\mathrm{O}$ & B & SB \\
\hline Licinus italicus & $\mathrm{L}$ & $\mathrm{F}$ & B & NA \\
\hline Lophoglossus gravis & $\mathrm{L}$ & $\mathrm{F}$ & NA & NA \\
\hline
\end{tabular}


Table S2 (continued)

\begin{tabular}{|c|c|c|c|c|}
\hline Species & Body size & Habitat affinity & Wing form & Breeding \\
\hline Mecodema fulgidum & $\mathrm{L}$ & G & NA & NA \\
\hline Mecodema rugiceps & $\mathrm{L}$ & $\mathrm{F}$ & NA & NA \\
\hline Micratopus aenescens & S & NA & NA & NA \\
\hline Molops piceus & M & $\mathrm{F}$ & B & SB \\
\hline Nebria asturiensis & M & $\mathrm{F}$ & B & NA \\
\hline Nebria brevicollis & M & G & M & $A B$ \\
\hline Nebria tibialis & M & $\mathrm{F}$ & NA & NA \\
\hline Notiobia terminata & M & $\mathrm{O}$ & M & SB \\
\hline Notiophilus aestuans & S & $\mathrm{O}$ & M & SB \\
\hline Notiophilus biguttatus & $S$ & $\mathrm{~F}$ & $\mathrm{D}$ & SB \\
\hline Notiophilus palustris & $S$ & G & $\mathrm{D}$ & SB \\
\hline Notiophilus rufipes & $S$ & G & $\mathrm{D}$ & SB \\
\hline Notiophilus sylvaticus & $S$ & $\mathrm{O}$ & $\mathrm{D}$ & SB \\
\hline Notonomus variicollis & $\mathrm{L}$ & NA & NA & NA \\
\hline Omus dejeanii & $\mathrm{L}$ & $\mathrm{F}$ & B & SB \\
\hline Oodes amaroides & M & G & M & SB \\
\hline Oxypselaphus obscurus & $S$ & G & $\mathrm{D}$ & SB \\
\hline Panagaeus bipustulatus & S & $\mathrm{O}$ & M & SB \\
\hline Paratachys sp. & S & NA & M & SB \\
\hline Paraxinidium andreaei & $S$ & NA & NA & NA \\
\hline Piesmus submarginatus & M & $\mathrm{F}$ & NA & NA \\
\hline Platyderus neapolitanus & $S$ & $\mathrm{~F}$ & NA & NA \\
\hline Platyderus rufus & $S$ & G & $\mathrm{B}$ & $\mathrm{AB}$ \\
\hline Platynus assimilis & M & $\mathrm{F}$ & M & SB \\
\hline Platynus decentis & M & $\mathrm{F}$ & M & SB \\
\hline Platynus krynickii & M & $\mathrm{F}$ & M & SB \\
\hline Platynus magnus & $\mathrm{L}$ & G & M & $\mathrm{AB}$ \\
\hline Poecilus chalcites & M & $\mathrm{O}$ & M & SB \\
\hline Poecilus cupreus & M & $\mathrm{O}$ & M & SB \\
\hline Poecilus koyi & M & $\mathrm{O}$ & NA & NA \\
\hline Poecilus lepidus & $\mathrm{L}$ & $\mathrm{O}$ & $\mathrm{D}$ & $\mathrm{AB}$ \\
\hline Poecilus versicolor & M & $\mathrm{O}$ & M & SB \\
\hline Promecognathus crassus & M & G & NA & NA \\
\hline
\end{tabular}


Table S2 (continued)

\begin{tabular}{|c|c|c|c|c|}
\hline Species & Body size & Habitat affinity & Wing form & Breeding \\
\hline Pseudoophonus rufipes & $\mathrm{L}$ & $\mathrm{O}$ & M & $\mathrm{AB}$ \\
\hline Pterostichus adstrictus & M & G & M & SB \\
\hline Pterostichus amethystinus & $\mathrm{L}$ & $\mathrm{F}$ & NA & NA \\
\hline Pterostichus anthracinus & M & G & $\mathrm{D}$ & SB \\
\hline Pterostichus brevicornis & S & $\mathrm{F}$ & $\mathrm{B}$ & $\mathrm{AB}$ \\
\hline Pterostichus burmeisteri & $\mathrm{L}$ & F & B & SB \\
\hline Pterostichus cantaber & $\mathrm{L}$ & $\mathrm{F}$ & B & NA \\
\hline Pterostichus cantabricus & S & $\mathrm{F}$ & $\mathrm{B}$ & NA \\
\hline Pterostichus castaneus & M & NA & B & NA \\
\hline Pterostichus cristatus & $\mathrm{L}$ & $\mathrm{F}$ & $\mathrm{B}$ & SB \\
\hline Pterostichus ebenus & $\mathrm{L}$ & G & B & $\mathrm{AB}$ \\
\hline Pterostichus haesitatus & M & $\mathrm{F}$ & NA & NA \\
\hline Pterostichus haptoderoides & $S$ & G & M & SB \\
\hline Pterostichus herculaneus & $\mathrm{L}$ & $\mathrm{F}$ & $\mathrm{B}$ & $A B$ \\
\hline Pterostichus hungaricus & $\mathrm{L}$ & G & $\mathrm{B}$ & NA \\
\hline Pterostichus inanis & M & F & NA & NA \\
\hline Pterostichus lama & $\mathrm{L}$ & $\mathrm{F}$ & $\mathrm{B}$ & NA \\
\hline Pterostichus lattini & $\mathrm{L}$ & $\mathrm{F}$ & $\mathrm{B}$ & SB \\
\hline Pterostichus madidus & $\mathrm{L}$ & $\mathrm{F}$ & B & $\mathrm{AB}$ \\
\hline Pterostichus melanarius & $\mathrm{L}$ & G & $\mathrm{D}$ & $\mathrm{AB}$ \\
\hline Pterostichus melas & $\mathrm{L}$ & G & $\mathrm{B}$ & NA \\
\hline Pterostichus micans & $\mathrm{L}$ & $\mathrm{F}$ & NA & NA \\
\hline Pterostichus microcephalus & M & G & M & $A B$ \\
\hline Pterostichus niger & $\mathrm{L}$ & G & M & $\mathrm{AB}$ \\
\hline Pterostichus oblongopunctatus & M & $\mathrm{F}$ & M & SB \\
\hline Pterostichus ovoideus & $\mathrm{S}$ & G & $\mathrm{D}$ & SB \\
\hline Pterostichus pohnerti & M & NA & NA & NA \\
\hline Pterostichus protractus & $\mathrm{L}$ & $\mathrm{F}$ & NA & SB \\
\hline Pterostichus riparius & $S$ & $\mathrm{~F}$ & $\mathrm{~B}$ & NA \\
\hline Pterostichus strenuus & $S$ & G & $\mathrm{D}$ & SB \\
\hline Pterostichus sulcitarsis & S & G & M & SB \\
\hline Pterostichus trinarius & $\mathrm{L}$ & $\mathrm{F}$ & $\mathrm{B}$ & SB \\
\hline Pterostichus tuberculofemoratus & M & $\mathrm{F}$ & NA & NA \\
\hline
\end{tabular}


Table S2 (continued)

\begin{tabular}{|c|c|c|c|c|}
\hline Species & Body size & Habitat affinity & Wing form & Breeding \\
\hline Scaphinotus angulatus & $\mathrm{L}$ & $\mathrm{F}$ & B & NA \\
\hline Scaphinotus angusticollis & $\mathrm{L}$ & $\mathrm{F}$ & B & NA \\
\hline Scaphinotus marginatus & $\mathrm{L}$ & F & B & $\mathrm{AB}$ \\
\hline Scaphinotus rugiceps & $\mathrm{L}$ & $\mathrm{F}$ & B & NA \\
\hline Scarites sp. & $\mathrm{L}$ & $\mathrm{O}$ & M & NA \\
\hline Semiardistomis viridis & S & NA & M & NA \\
\hline Sericoda bembidioides & $S$ & G & M & NA \\
\hline Sericoda quadripunctata & $S$ & $\mathrm{~F}$ & M & SB \\
\hline Stenolophus ochropezus & $S$ & G & M & SB \\
\hline Stomis pumicatus & $S$ & G & B & SB \\
\hline Syntomus americanus & $S$ & $\mathrm{O}$ & $\mathrm{D}$ & SB \\
\hline Syntomus foveatus & S & $\mathrm{O}$ & B & SB \\
\hline Syntomus pallipes & $S$ & G & B & $\mathrm{SB}$ \\
\hline Syntomus truncatellus & $S$ & G & B & SB \\
\hline Synuchus arcuaticollis & M & G & B & $\mathrm{AB}$ \\
\hline Synuchus cycloderus & M & $\mathrm{F}$ & M & $\mathrm{AB}$ \\
\hline Synuchus dulcigradus & M & $\mathrm{F}$ & M & $\mathrm{AB}$ \\
\hline Synuchus impunctatus & M & G & $\mathrm{D}$ & $\mathrm{AB}$ \\
\hline Synuchus nitidus & $\mathrm{L}$ & $\mathrm{F}$ & $\mathrm{D}$ & $\mathrm{AB}$ \\
\hline Synuchus vivalis & $S$ & $\mathrm{O}$ & $\mathrm{D}$ & $\mathrm{AB}$ \\
\hline Trachypachus holmbergi & $S$ & $\mathrm{O}$ & NA & $\mathrm{SB}$ \\
\hline Trechus chalybeus & $S$ & G & $\mathrm{B}$ & SB \& AB \\
\hline Trechus obtusus & $S$ & $\mathrm{O}$ & $\mathrm{D}$ & SB \\
\hline Trechus quadristriatus & $S$ & $\mathrm{O}$ & $\mathrm{D}$ & $\mathrm{AB}$ \\
\hline Trichotichnus nitens & $S$ & $\mathrm{~F}$ & NA & NA \\
\hline Zacotus matthewsii & $\mathrm{L}$ & $\mathrm{F}$ & B & NA \\
\hline
\end{tabular}




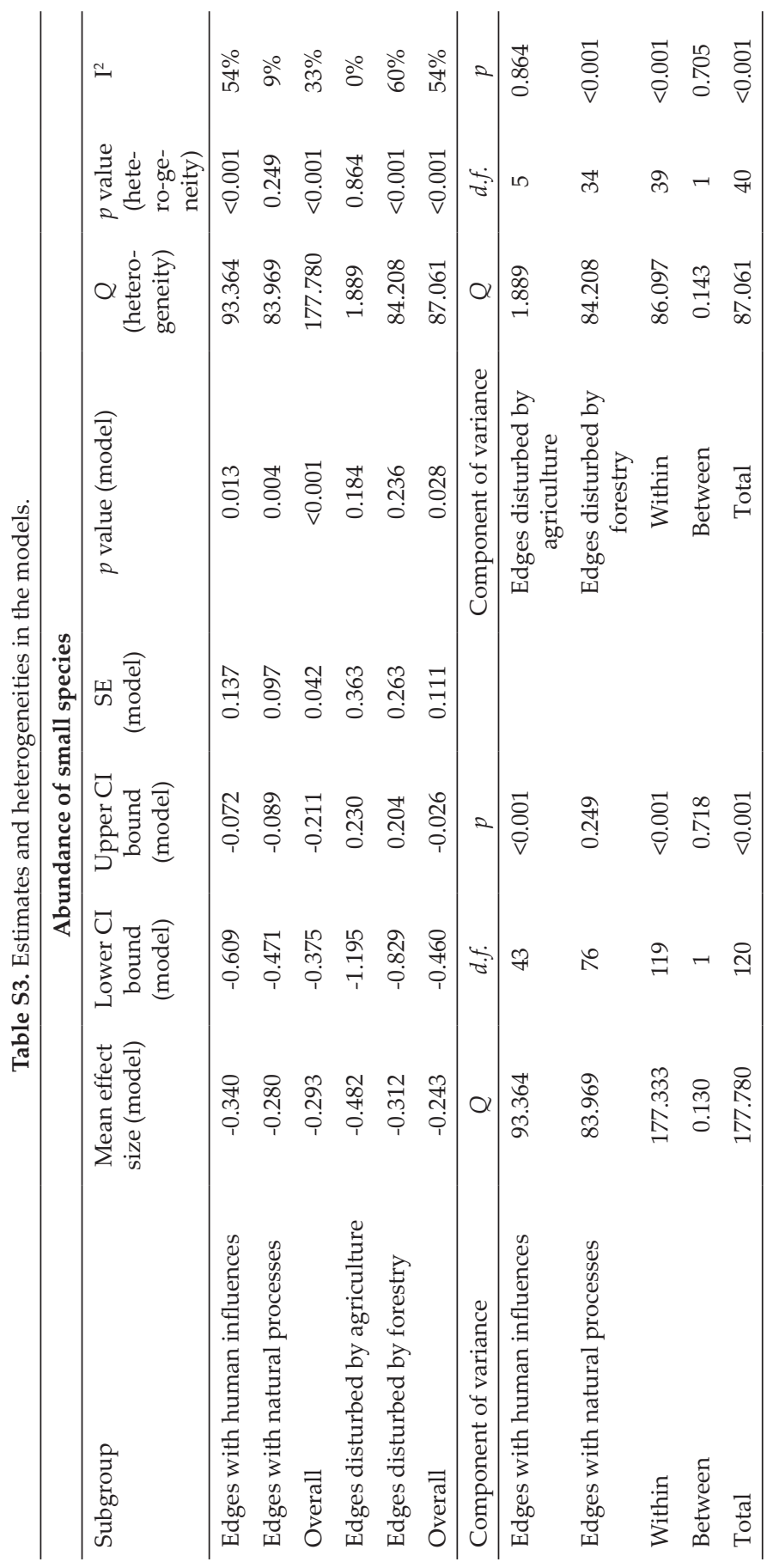




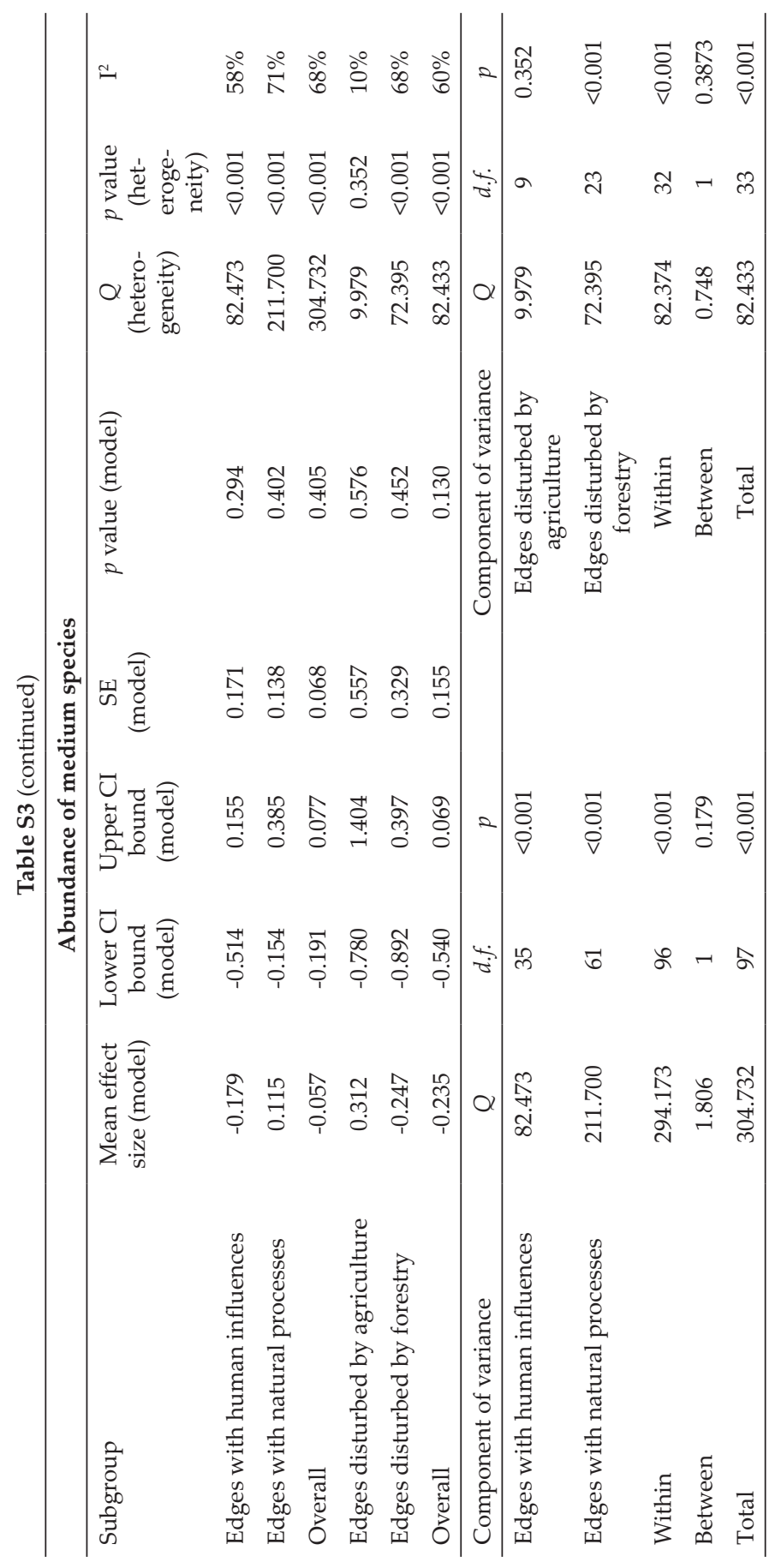




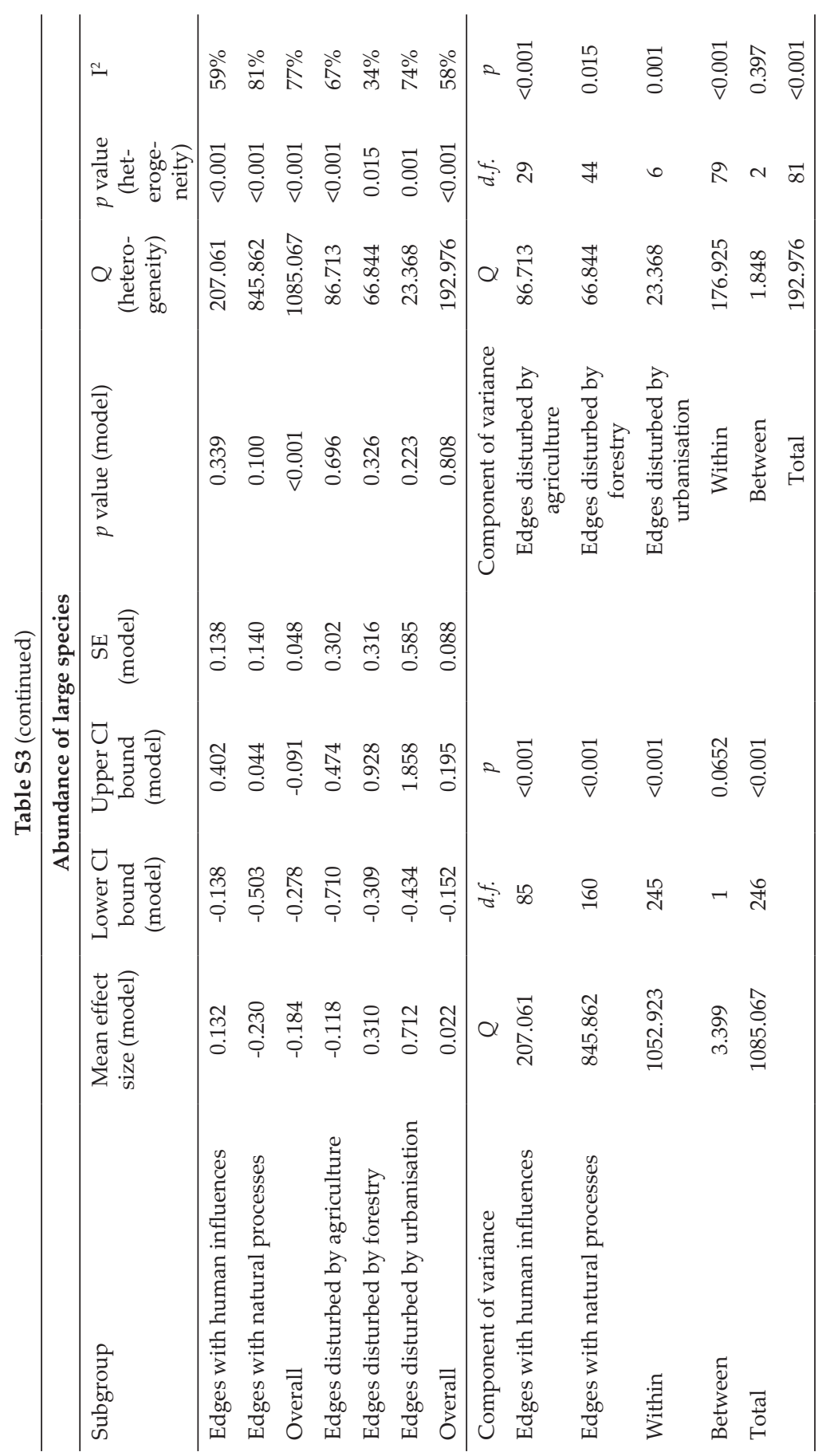



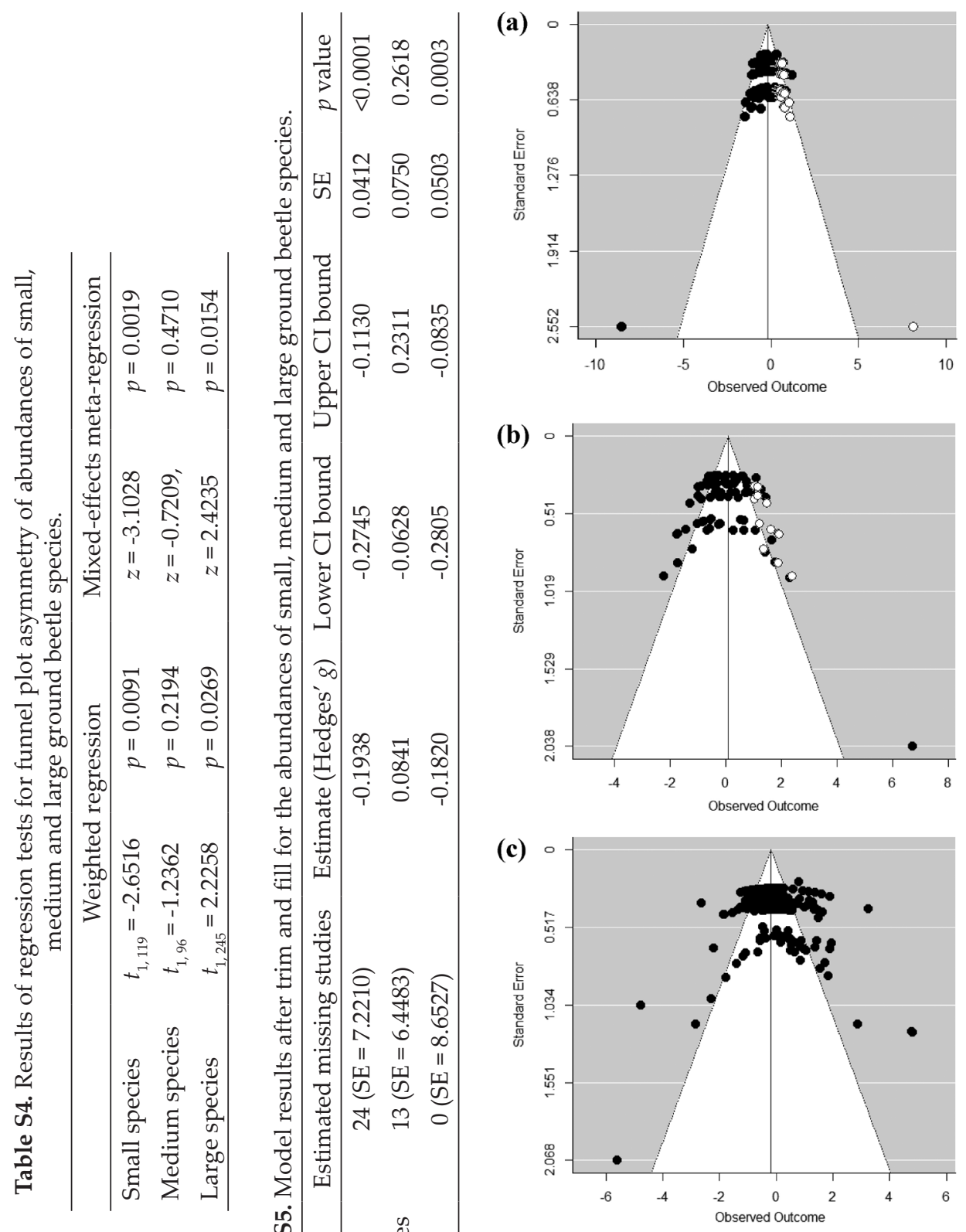

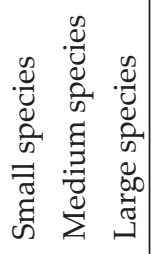

Fig. S1. Funnel plots of the abundance of small (a), medium (b), and large ground beetle species (c) with missing studies (empty circles) estimated by the trim and fill method 